\title{
Molecular approach of the fragile chromosomal region Xq31-34 in cattle (Bos taurus) by microdissection and DOP-PCR
}

\author{
[Aproximação molecular da região cromossômica frágil Xq31-34 em bovinos \\ (Bos taurus) utilizando microdissecação cromossômica e DOP-PCR]

$$
\text { S. Llambi } i^{*}, \text { M.V. Arruga }{ }^{2}
$$ \\ ${ }^{1}$ Facultad de Veterinaria - UdeLAR \\ A. Lasplaces 1550 CP11600 - Montevideo, Uruguay \\ ${ }^{2}$ Facultad de Veterinaria - Universidad de Zaragoza - Zaragoza, Spain
}

\begin{abstract}
Fragile sites (FS) are chromosomal regions where the normal compactation of chromatine is not observed. FRAXA (Fra Xq27.3, X sexual chromosome) is one of the most studied FS in humans. FRAXA is an expansion of the trinucleotide CGG located in the gene FMR-1. In cattle, sites of chromosomal fragility were reported in BTAX, associated with different pathologies and fertility impairment. Chromosomal microdissection has became a valuable tool for isolating chromatine fragments. In this work, it was combined the chromosomal microdissection technique with DOP-PCR in order to carry out a molecular analysis of the fragile chromosomal region BTAXq31-34. In that region, polymorphic DNA-RAPD sequences (GC rich) are present and sequences of the gene FMR-1 are missing. The results showed the usefulness of the microdissection-DOP-PCR technique for molecular characterization of fragile chromosomal sites in cattle.
\end{abstract}

Keywords: cattle, fragile sites, DOP-PCR, microdissection, X sexual chromosome

\section{RESUMO}

Os sítios frágeis (FS) são regiões de cromossomo onde a compactação normal da cromatina não é realizada. O FRAXA (Fra Xq27.3, cromossomo sexual X) é um dos FS mais estudados em seres humanos. O FRAXA apresenta expansão do trinucleotídeo CGG localizado no gene FMR-1. Em bovinos, existem estudos informando sobre fragilidade cromossômica em BTAX associada com diversas patologias $e$ alterações na fertilidade. A microdissecação cromossômica é uma valiosa técnica para isolar fragmentos de cromatina. Neste trabalho, combinou-se a técnica de microdissecação de cromossomo com DOP-PCR para executar a análise molecular da região do sitio frágil cromossômico BTAXq31-34. Naquela região estão presentes seqüencias do polimorfo DNA-RAPD (rico em GC), em que as seqüências do gene FMR1 estão ausentes. Os resultados mostram a utilidade da técnica de microdissecação-DOP-PCR para a caracterização molecular de sítios frágeis cromossômicos em bovinos.

Palavras-chave: bovino, sítios frágeis, DOP-PCR, microdissecação, cromossomo sexual X

\section{INTRODUCTION}

Fragile sites (FS) are regions of the chromatine where the normal compactation is not observed during mitosis, being conserved in evolution (Sutherland, 2003). In domestic animals (dog, swine, and, horse) fragile regions of the $\mathrm{X}$ chromosome were detected, related to pathologies such as cancer, chromosomal rearrangements, and fertility alterations (Stone et al., 1991; Riggs et al., 1993). In different cattle breeds, chromosomal fragility has been identified in autosomes and in the sexual X chromosome (BTAX) associated with reproductive anormalities, bald calf syndrome, and dwarfism (Hanada and Muramatsu, 1980; Uchida et al.,

Recebido em 21 de março de 2007

Aceito em 18 de junho de 2008

E-mail: silvia.1lambi@gmail.com 
1986; Llambí and Postiglioni, 1994). In this species, a fragile site was discovered in the region FRAXq3.1, associated with fertility problems such as repeat breeders, long calving interval, and abortions (Rincón et al., 1997; Slota et al., 2000; Danielak-Czech and Slota, 2004).

Structural chromosome instability is considered to reflect DNA damage which, if not repaired, result in chromosomal or genic mutation (Danielak-Czech and Slota, 2004).

Authors have identified homologous sequences of the gene FMR1 associated to human fragile X chromosome by means of PCR and sequencing using specific primers in cattle DNA (Llambí et al., 2003). This gene shows dynamic mutations due to CGG repeats, causing $X$ sexual chromosome fragility (Sutherland, 2003).

In the last years, chromosomal microdissection with DOP-PCR technique has been used in cattle in order to generate molecular markers associated with quantitative trait loci (QTL), DNA probes, and in studies on chromosomal rearrangements in pathologies and karyotype evolution (Goldammer et al., 1996; Ponce de León et al., 1996; Schwerin, 2001; Slota et al., 2003).

At the evolutionary level, the use of laser microdissection and painting probe in the Bovidae family has shown that the $\mathrm{X}$ chromosome has suffered complex rearrangements, such as transpositions that do not involve changes in the order of the genes (Pauciullo et al., 2006). This type of rearrangement is associated to chromosomal instability regions (breakpoints), where repetitive sequences are present, such as LINEs (AT rich) or SINE (CG-rich) (Schibler et al., 2006).

The aim of this work was to accomplish a molecular approach to know which type of sequences are present in the fragile region BTAXq31-34, using the chromosomal microdissection technique combined with a preamplification with universal primers and amplification with specific primers (DOP-PCR).

\section{MATERIAL AND METHODS}

Metaphase spreads were prepared from two Holstein-Friesian cows lymphocyte cultures in
RPMI $1640^{1}$ complete medium using standard cytogenetic techniques. For RBG banding 5bromo-2'deoxyuridine, BrdU $\left(20 \mu \mathrm{g} \mathrm{ml}^{-1}\right)$ was incorporated into the cells six hours before harvesting. Air-dried chromosomes slides were incubated with Hoechst $33258\left(4 \mathrm{mg} \mathrm{l}^{-1}\right)$ in $0.9 \%$ $\mathrm{NaCl}$ during 30min and exposed to a black-ray lamp for 15min (Llambí and Postiglioni, 1996).

The fixed cells were dropped onto $24 \times 50 \mathrm{~mm}$ cover slips and stored under sterile conditions at room temperature for three to five days. All chromosome manipulations were observed under inverted microscope (magnification 1.000x) with a micromanipulator ${ }^{2}$. The region to be microdissected was identified by RBG banding (BTAXq31-34) acording to the bovine idiogram (Di Berardino et al., 2001).

Microdissection of 20 pieces of this chromosomal region was performed with microcapillars of borosilicate glass ${ }^{3}$. In order to avoid DNA contamination, all microneedles were freshly prepared for each dissection and treated with ultraviolet light for 15 minutes prior to use (Kao., 1993).

Dissected chromosomal fragments attached to the glass needles were transferred to $0.5 \mathrm{ml}$ Eppendorf tubes, to which 5ul of double deionized sterile water was added, and heatdenatured at $95^{\circ} \mathrm{C}$ for $10 \mathrm{~min}$ according to Yokoyama et al. (1997). The DNA was then preamplified by $\mathrm{PCR}$ in a $25 \mathrm{ul}$ reaction containing $1.5 \mathrm{U}$ Taq DNA polymerase, $2.5 \mathrm{ul}$ DOP-PCR buffer, 1X (10nM Tris-HCl, 50nM $\mathrm{KCl}, 1.5 \mathrm{nM} \mathrm{MgCl} 2$ ), 200uM of each dNTPs and 5 pmol of the degenerate oligonucleotide primer (5'-CCGACTCGAGNNNNNNATGTGG3').

The thermocycling program consisted of $95^{\circ} \mathrm{C}$ for $5 \mathrm{~min}$, five cycles of $94^{\circ} \mathrm{C}$ for $1 \mathrm{~min}, 30^{\circ} \mathrm{C}$ for $1.5 \mathrm{~min}$, and $72^{\circ} \mathrm{C}$ for $3 \mathrm{~min}$ followed by 35 cycles of $94^{\circ} \mathrm{C}$ for $1 \mathrm{~min}, 62^{\circ} \mathrm{C}$ for $1 \mathrm{~min}$, and $72^{\circ} \mathrm{C}$ for $2 \mathrm{~min}$. The amplification protocol was based in part on the DOP-PCR work of Telenius et al. (1992).

Finally, four pairs of primers and one oligonucleotide type RAPDs (10pmol of each

\footnotetext{
${ }^{1}$ Sigma Co. - St. Louis, USA.

${ }^{2}$ Olympus - Tokyo, Japan.

${ }^{3}$ Gc 100-10, Clark Electrom. Inst. - Edenbridge, England.
} 


\section{Llambí et al.}

primer) were analysed in separate $0.5 \mathrm{ml}$ Eppendorf tubes by PCR (200uM of each dNTPs, $14 \mathrm{mM}$ Tris- $\mathrm{HCl}, 3.5 \mathrm{mM} \mathrm{MgCl} 2,50 \mathrm{mM}, 2 \mathrm{U}$ Taq polymerase), using $5 \mathrm{ul}$ aliquots of the preamplified DNA in a final volume of 50ul. The characteristics of the primer pairs and conventional PCR programs are shown in Table 1. Bovine genomic DNA was used as positive control.

Table 1. Characteristics of molecular markers from dairy cows

\begin{tabular}{|c|c|c|c|c|}
\hline $\begin{array}{l}\text { Name and type } \\
\text { of marker }\end{array}$ & $\begin{array}{c}\text { Primer sequences [ } 5^{\prime}-3^{\prime} \text {; forward } \\
\text { (above) and reverse (below)] }\end{array}$ & $\begin{array}{c}\text { PCR size } \\
(\mathrm{bp})\end{array}$ & $\begin{array}{c}\text { Anneling } \\
\left({ }^{\circ} \mathrm{C}\right)\end{array}$ & $\begin{array}{l}\text { accesion } \\
\text { number, ref. }\end{array}$ \\
\hline $\begin{array}{l}\text { AR (bovine androgen } \\
\text { receptor gene } \\
\text { Xq2.4-2.5, } \\
\text { Type I }\end{array}$ & $\begin{array}{l}\text { CGAGAGCTGCATCAGTTCAC } \\
\text { GGATCTTGGGCACTTGCAC }\end{array}$ & 110 & 58 & Z75314 \\
\hline $\begin{array}{l}\text { ESTL08239, } \\
\text { sequence Xq3.1, } \\
\text { Type I }\end{array}$ & $\begin{array}{l}\text { CTACGGCATGGCATACAC } \\
\text { ATCAGTGGCACCCTGAG }\end{array}$ & 150 & 58 & L08239 \\
\hline $\begin{array}{l}\text { P4/P6, } \\
\text { oligonucleotides of human } \\
\text { gene FMR-1 } \\
\text { Type I }\end{array}$ & $\begin{array}{l}\text { GCTCAGCTCCGTTTCGGTTT } \\
\text { CACTTCCGGT } \\
\text { AGCCCCGCACTTCCACCACC } \\
\text { AGCTCCTCCA }\end{array}$ & 250 & 70 & $\begin{array}{l}\text { AF323120, } \\
\text { GDB: } 187391\end{array}$ \\
\hline $\begin{array}{l}\text { IDVGA } 82, \quad \text { microsatellite } \\
\text { Xq3.4, } \\
\text { Type II }\end{array}$ & $\begin{array}{l}\text { ACAATGATGAGGGGCTCTG } \\
\text { GGCAAACCATTCCAGTATTC }\end{array}$ & 191 & 58 & X86813 \\
\hline $\begin{array}{l}\text { UBC413, RAPD, } \\
\text { Type II }\end{array}$ & GAGGCGGCGA & $100-800$ & 36 & $\begin{array}{l}\text { University of } \\
\text { British } \\
\text { Columbia }\end{array}$ \\
\hline
\end{tabular}

\section{RESULTS}

The initial products obtained by DOP-PCR generated a smear pattern from 100 to $800 \mathrm{bp}$ for all the microdissected fragments (Fig. 1).

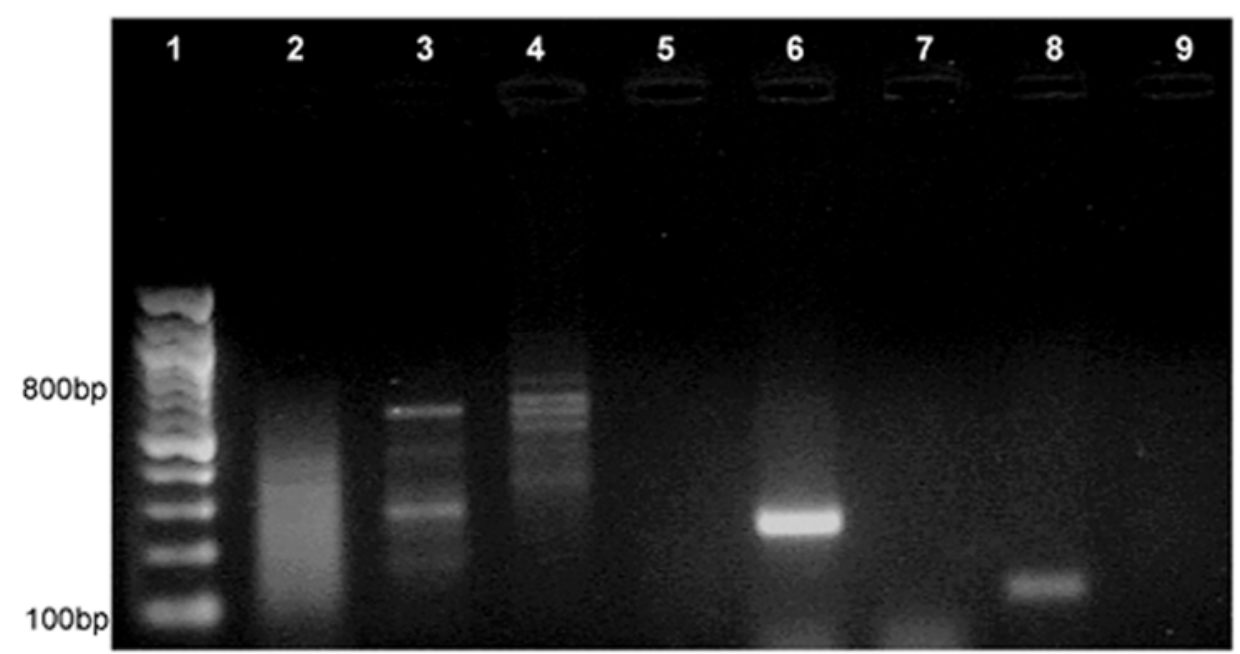

Figure 1. Photograph of ethidium bromide-stained agarose gel. Lane 1: DNA molecular weight marker (100bp ladder); lane 2: DOP-PCR amplified (smear of DNA ranging in size from about 100-800bp); lane 3: amplification of RAPD413 after preamplification with DOP-PCR; lane 4: amplification of RAPD413 from the cattle genomic DNA; lane 5: negative control (no template); lane 6: amplification of P4/P6 from the cattle genomic DNA; lane 7: no amplification of P4/P6 after preamplification with DOP-PCR; lane 8: amplification of AR from the cattle genomic DNA; lane 9: no amplification of AR after preamplification with DOP-PCR. 
The type II molecular marker RAPD UBC413 amplified a pattern of two bands (200bp and $800 \mathrm{bp}$ ) in the DNA isolated by microdissection; while in the bovine DNA control, this marker showed more variability of bands including the common band of $800 \mathrm{bp}$. The markers P4-P6, AR, and ESTL08239 amplified the positive bovine controls but not the DNA obtained from microdissection (Fig. 1).

The amplification of a band of the expected size (191bp) with the primers IDVGA82 (mapped to the Xq34) demonstrated the specificity of the microdissection process on the fragile region (region Xq31-34). On the other hand, the specific primers of the human FMR-1 (P4/P6) were not amplified.

\section{DISCUSSION}

The first chromosomal microdissection in domestic animals was achieved in 1994 (Schmutz et al., 1994). These authors developed a cattle DNA library from chromosomal rearrangements (Robertsonian translocation). Most works in domestic animals including chromosomal microdissection have focused in the construction of probes for physical mapping, construction of DNA libraries, studies on chromosomal rearrangements, and karyotypic evolution (Pinton et al., 2003; Li et al., 2005). The results showed in the present work validate the application of this technique for molecular approachs of fragile chromosomal regions in cattle.

Analyzing the genomic DNA of different cattle breeds, Rincón et al. (2000) obtained a specific band pattern amplification using the marker UBC413 ( $80 \%$ of GC). In the DNA of the microdissected region, in this work, only two bands were amplified with this marker. This was an expected result, since a small portion of the bovine genome was used for the amplification. Future sequencing and characterization of these amplified bands (SCAR) could give information about the type of sequences present in such an unstable chromosomal region.

Sexual chromosome $\mathrm{X}$ is conserved in mammal evolution, showing a high concentration of LINEs (AT rich) dispersed sequences (Asai et al., 2004). However, Monteagudo et al. (1999), using the FISH technique with a probe of CGG repeats, found hybridization signals in the medium region of the $\mathrm{q}$ arm (Xq31) of the bovine $\mathrm{X}$ chromosome. In the present work, because the FMR-1 gene sequences were not amplified, the possible presence of CGG repeats due to dynamic mutations of this gene was discarded. In spite if this, it was not possible rule out the possible presence of other genes with dynamic mutations in this region, rich in $\mathrm{CGG}$ repeats acording to Monteagudo et al. (1999) findings. Even if it was demostrated that FMR1 gene sequences were not present in the DNA pool of this instability region, it must be taken into account that the amplification products obtained by chromosomal microdissection are composed of a complex collection of chromosomal fragments. Ponce de León et al. (1996) developed specific bovine DNA libraries of chromosome $\mathrm{X}$ regions combining methods of microdissection and PCR amplification with adapter primers. According to the used methods, these authors estimated that the chromosomal fragments represented around $75 \%$ of the microisolated DNA. According to the experiences of the authors of the present study, the use of universal degenerated short primers (DOP-PCR) allowed to obtain a uniform amplification from small DNA samples (microdissected fragments).

The importance of studying bovine fragile sites at the molecular level lays in the reproductive potential of breeding animals and in the relationship between the $\mathrm{X}$ chromosome fragile regions and fertility alterations.

Danielak-Czech and Slota (2004) suggested the existence of unappropriate expression of genes related to fertility in region $\mathrm{Xq} 2.4-\mathrm{Xq} 3.1$, due to the excessive chromosomal instability found in cows with reproductive problems.

Asai et al. (2004), mapped the trophinin (TRO) gene to bovine region Xq25-33, which codes for a protein involved in embryo implantation. Using the technique described in that work, it will be possible to study in depth this gene at the cytomolecular level, being a candidate gene for reproductive problems associated to chromosomal fragility in bovines.

The amplification of a band of the expected size (191bp) with the primers set IDVGA82 (mapped to Xq34) demonstrated the specificity of the 
microdissection process. Moreover, not amplifying with the set of primers AR (mapped to Xq26) and ESTL08239 (mapped to Xq31) limited the microdissected region under this chromosome band.

In conclusion, this study demonstrates that chromosomal microdissection and DOP-PCR techniques are valuable tools for the study of chromosomal fragility regions and bovine gene mapping. DNA-RAPD sequences (GC rich) are present and sequences of the gene FMR-1 are absent. This would aid in the physical cloning and characterization of those bovine chromosomal regions.

\section{ACKNOWLEDGEMENTS}

We thank Dr. Maite Calvo (Hospital Infantil Miguel Servet, Zaragoza, Spain) for constant interest in this work and Miss Iris Hernández for the technical assistance. This work was supported by a Research Project from UNIZAR (Spain) and CSIC (UdeLAR, Uruguay).

\section{REFERENCES}

ASAI, M.; GRAPHODATSKAYA, D.; STRNZINGER, G. et al. Assignment of bovine trophinin (TRO) to the $\mathrm{q}$ arm of the $\mathrm{X}$ chromosome by fluorescence in situ hybridization. Anim. Genet., v.35, p.157-158, 2004.

DANIELAK-CZECH, B.; SLOTA, E. Mutageninduced chromosome instability in farm animals. J. Anim. Feed. Sci., v.13, p.257-267, 2004.

DI BERARDINO, D.; DI MEO, G.; GALLAGHER, D.E. et al. ISCNDB 2000 International System for chromosome nomenclature of domestic bovids. Cytogenet. Cell Genet., v.92, p.283-299, 2001.

GOLDAMMER, T.; WEIKARD, R.; BRUNNER, R. et al. Generation of chromosome fragment specific bovine ADN sequences by microdissection and DOP-PCR. Cytogenet. Cell. Genet., v.7, p.291-296, 1996.

HANADA, H.; MURAMATSU, S. A case of subfertile cow with structural abnormalities of the X chromosome. Ann. Genet. Sel. Anim., v.12, p.209-213, 1980.
KAO, F. Microdissection and microcloning of human chromosome regions in genome and genetic disease analysis. BioEssays, v.15, p.141$145,1993$.

LI, D.; LIU, W.; TAKASUGA, A. et al. Characterization and RH mapping of bovine microsatellites generated from a microdissected BTA20-specific DNA library. Anim. Gent., v.26, p.146-151, 2005.

LLAMBÍ, S.; RODRÍGUEZ, V.; CALVO, M.T. et al. Sequenciamiento de fragmentos de DNA bovino revela homologia com região do gene FMR-1 em mamiferos, In: CONGRESSO NACIONAL DE GENÉTICA, 49., 2003., Águas de Lindóia. Anais... Águas de Lindóia: SBG, 2003. p.109.

LLAMBI, S.; POSTIGLIONI, A. Frequencies and cytomorphological manifestation of sexual $\mathrm{X}$-chromosome fragility (FRA $\mathrm{Xq} 3.1$ ) in Holstein- Friesian. Arch. Zootec., v.45, p.203208, 1996.

LLAMBÍ, S.; POSTIGLIONI, A. Localization of the fragile $\mathrm{X}$ chromosome breaks points in Holstein-Friesian cattle (Bos taurus). Theriogenology, v.42, p.789-794, 1994.

MONTEAGUDO, L.V.; POSTIGLIONI, A.; LLAMBÍ, S. et al. Detection of chromosome breaks and genetic pathology by molecular genetics. Hung. J. Anim. Produc., v.48, p.150152, 1999.

PAUCIULLO, A.; KUBICKOVA, S.; CERNOHORSKA, $H$. et al. Isolation and physical localization of new chromosome specific centromeric repeats in farm animals. Vet. Med., v.51, p.224-231, 2006.

PINTON, A.; DUCOS, A.; YERLE, M. Chromosomal rearrangements in cattle and pigs revealed by chromosome microdissection and chromosome painting. Genet. Sel. Evol., v.35, p.685-696, 2003.

PONCE DE LEON, A.; AMBADY, S.; HAWKINS, G. et al. Development of a bovine $\mathrm{X}$ chromosome linkage group and painting probes to assess cattle, sheep and goat X chromosome segment homologies. Proc. Natl. Acad. Sci., v,93, p.3450-3454, 1996.

RIGGS, P.K.; KUCZCK, T.; CHRISMAN, C.L. et al. Analysis of aphidicolin-induced chromosome fragility in the domestic pig (Sus 
scrofa), Cytogenet. Cell. Genet., v.62, p.110-116, 1993.

RINCÓN, G.; D'ANGELO, M.; GAGLIARDI, R. et al. Genomic polymorphism in Uruguayan Creole cattle using RAPD and microsatellite markers. Res. Vet. Sci., v.69, p.171-174, 2000.

RINCÓN, G.; LLAMBÍ, S.; POSTIGLIONI, A. Expression of $\mathrm{X}$ chromosome fragility in Holstein-Friesian cattle, a preliminary study. Genet. Sel. Evol., v.29, p.395-401, 1997.

SCHIBLER, L., ROIG, A., MAHE, M.F. et al. High-resolution comparative mapping among man, cattle and mouse suggest a role for repeat sequences in mammalian genome evolution. BMC Genomics, v.7, p.194-205, 2006.

SCHMUTZ, S.M.; BERRYERE, T.G.; MOKER, J.S. et al. Gene Mapping from a Bovine 1/29 DNA Library Prepared with Chromosome Microdissection. Mamm. Genome, v.5, p.138141,1994

SCHWERIN, M. Molecular genome analysis in livestock at the beginning of the New Millenium. Reprod. Dom. Anim., v.36, p.133-138, 2001.

SLOTA, E.; DANIELAK-CZECH, B.; PIETRASSZEWSKA, J. et al. Preliminary identification of the fragile $\mathrm{X}$ in two crossbred cows. Vet. Med., v.45, p.308-310, 2000.

SLOTA, E.; KOZUBSKA, A.; KOSCIELNY, M. et al. Detection of the XXY trisomy in a bull by using sex chromosome painting probe. $J$. Appl. Genet., v.44, p.379-382, 2003.

STONE, M.; JACKY, P.; HANCOCK, D. et al. Animal Model. Chromosomal Fragile Site Expression in Dogs, I. Breed Specific Diferences. Am. J. Med. Genet., v.40, p.214-222, 1991.

SUTHERLAND, G.R. Rare fragile sites. Cytogenet. Genome Res., v.100, p.77-84, 2003.

TELENIUS, H.; CARTER, N.; BEBB, C.E. et al. Degenerated oligonucleotide-primed PCR, general amplification of target DNA by a single degenerated primer. Genomic, v.13, p.718-725, 1992.

UCHIDA, L.; FREEMAN, V.; BASRUR, P. The fragile $\mathrm{X}$ in cattle. Am. J. Med. Genet., v.23, p.557-562, 1986.

YOKOHAMA, Y.; OHSUGU, K.; KOZAKI, T. et al. Microdissection-mediated selection of chromosome region-specific cDNAs, Cytogenet. Cell. Genet., v.77, p.192-196, 1997. 